\title{
Healthy Living Behaviors in University Students and Related Factors
}

\author{
(1) Albena Gayef \\ Department of Medical Education, Trakya University, Faculty of Medicine, Edirne, Turkey
}

\section{ABSTRACT}

Today, health is considered to be a biopsychosocial, that is to say, a complete good of individuals, which also means an increase in quality of life and satisfaction. Healthy living behavior is the control of all behaviors that are applied to protect against diseases affecting individual health and the individual choosing behaviors that are appropriate to his/her health conditions in regulating daily activities. In this review, it is aimed to present healthy living behavior, importance of healthy living behavior, research results on healthy living behavior and related factors and make suggestions about healthy living behavior.

Keywords: Health, life, behavior, students, universities

\section{INTRODUCTION}

Today, health is considered to be a biopsychosocial, that is to say, a complete good of individuals, which also means an increase in quality of life and satisfaction. In 2000 World Health Organization emphasized the importance of healthy living behaviors as "Health for All" in its statement. The goal is to increase the number of healthy individuals, and in order to achieve this goal, it is necessary to increase the quality of life and decrease the negative health conditions. Efforts to promoting health for people to maximize their health behaviors have great importance. One of the fundamental rights of every human being is to be healthy, based on to preserve and maintain health, and promotion of health. ${ }^{[1]}$

Please cite this article as: Gayef A. Healthy Living Behaviors in University Students and Related Factors. Anatol J Family Med 2019;2(1):2-6.

Address for correspondence: Dr. Albena Gayef. Department of Medical Education, Trakya University Faculty of Medicine, Edirne, Turkey

Phone: +90 $2842357641 / 1563$

E-mail: albenag77@gmail.com

Healthy living behavior is the control of all behaviors that are applied to protect against diseases affecting individual health and the individual choosing behaviors that are appropriate to his/her health conditions in regulating daily activities. Behaviors that affect health in a positive way are behaviors that increase the level of well-being of individual and promote self-improvement. Within the context of healthy living behaviors, there are adequate and regular exercise, adequate and balanced nutrition, non-smoking, health responsibility, stress management and hygienic measures. ${ }^{[2]}$

It is very important that students have healthy life style in university period due to it has critical importance for their professional lifetime and general health. In this review, it is aimed to present healthy living behavior, importance of healthy living behavior, research results on healthy living behavior and related factors and present related research results.

Received Date: 07.09.2018

Accepted Date: 05.1.2018

Published online: 30.04 .2019

\section{METHOD}

In this review, detailed literature search was conducted at Google Academic with the keywords of "health, life, wellness, behavior, student, university". This study focuses on the results 
of research on university students' living behaviors and related factors.

\section{Investigations on Healthy Living Behaviors and Related Factors}

In this chapter, the results of national research on university students' healthy living behaviors and related factors will be explained. One of the studies related to healthy living behaviors and the related factors of university students was conducted with the first grade students of a Medical Faculty. As a result of the study with the aim of determining the factors affecting the healthy living behaviors of the students, students who live with their family made more physical activities than students live in dormitory; and students who have a fragmented family made more physical activities than students who have an unfragmented family; and students having an average perception of health made more physical activities than students having a high perception of health. It was determined that spiritual improvements of students have bad-the worst economic condition perception than students have the average best-good perception and their interpersonal relationships were worse than students have the best-good perception. In conclusion, it was found that those living together with their families, those with fragmented families, those with an average sense of health, those with higher economic sense have healthy living behaviors, and the economic condition is related with health perception and healthy living behavior of place..$^{[3]}$

When the relationship between health perception and health promotion behaviors of 361 nursing students in a High School of Nursing in Ankara and the results of a study conducted to examine the effect of education on health promotion behavior and health perception are examined, the behaviors that contribute to the health promotion in the subscales of healthy living behaviors scale (HLBS) mean score of self-actualization subscale was $35.8 \pm 7.3$, the mean score of health subscale was $26.2 \pm 6.5$, the mean score of interpersonal support subscale was $20.3 \pm 3.5$, the mean of stress management subscale was $18.2 \pm 3.4$, the mean of nutrition subscale was $17.2 \pm 3.3$, and the mean score of the exercise subscale was $12.2 \pm 4.0$. It was determined that $74.2 \%$ of the students perceived their health as "good" and $62.0 \%$ of them had a belief in their ability to control their health in the future as "too much". It was found that the students with high total score of HLSBS, perceive their health status as very good $(F=20.134, p<0.001){ }^{[4]}$

Another study was conducted as a descriptive-relationship seeker in order to determine the effect of education on health behaviors by revealing the change in healthy liv- ing behaviors of the first and the fourth-year students of High School of Nursing in Istanbul $(n=506)$. It was determined that $40 \%$ of the students spent a large part of their lives in the metropolitans and $83.4 \%$ of them perceived their health as good. It was found that age, working status, friendship relations and health perception affected healthy living behaviors. ${ }^{[5]}$

As a result of a research carried out as a descriptive study aiming to determine the healthy living behaviors of 268 students who are studying in a foundation university in Istanbul in the department of High School of Nursing, Faculty of Arts and Sciences, Conservatory, Faculty of Architecture, Faculty of Business Administration and Computer Engineering; the average score of subgroup of HLBS health responsibility of female students was statistically significant than males'; the average score of subgroup of health responsibility and nutrition health group of Nursing department students was statistically significant than other students; the average HLBS score of $4^{\text {th }}$ grade students was statistically significant than other grades' average score of the self-actualization and nutrition subgroup was statistically significant than bachelors; HLBS score averages of those have the best economical conditions, were statistically significant than others have average and good economical conditions. $(p<0.05)$. As a result of the research; economic status, duration of education, and marital status were found to have a positive effect on the healthy living behaviors of university students. ${ }^{[2]}$

In another study conducted to determine the healthy living behaviors of students in the health care vocational school of higher education $(n=128)$ and the demographic factors affecting these behaviors, the students had the highest score in the self-actualization subscale of HLBS and the lowest score in the physical activity subscale. In the study, it was observed that the HLSBS scores were changed according to the program type, high school graduated, having a chronic illness and the average daily sleep duration $(p<0.05)$. There was no difference between the students according to gender, grade level, health level and working variables $(p>0.05)$. Healthy living behaviors scores of students were found to be moderate in this study ${ }^{[6]}$

In another study conducted with the aim of determining the effect of socio-demographic characteristics and education processes of healthy students on the behaviors of healthy living behaviors of 132 students studying in the Department of Midwifery of Health College, the scores gained by students on healthy living behaviors examined according to variables as of married students, their fathers who had secondary school or above educational background, those with high monthly income, those whose monthly ne- 
cessities are met in adequate and those participate sport activities, have higher scores than the others and difference between them was statistically significant $(p<0.05)$. It was found that the highest average score was in self-actualization, interpersonal support and nutrition subgroups, marital status, parental educational background, monthly income level and participation in sports activities affected healthy living behaviors while the students' average score of HLSBS which was determined as moderate. ${ }^{[7]}$

In order to determine healthy living behaviors of health school students and factors affecting these, result of the study conducted with 688 students, it was determined that among the behaviors that contribute the health promotion, dimensions of self-actualization, health responsibility and interpersonal support has the highest average of scores and exercise has the lowest score average. The average score of the HLSBS is higher in those who are students in upper grades, perceived socio-economical levels as the moderate and high, non smokers, stated that they do exercises, those who assessed their health status as moderate and good $(p<0.05)$. Healthy living behaviors scores of students were found to be moderate. ${ }^{[1]}$

In another study conducted to determine healthy living behaviors and affecting factors of students of Health College at Nursing Department $(n=197)$, nutrition and health responsibility subscale scores of female students were found to be higher and more important than males' $(p<0.05)$. For male students, the average score of the exercise subscale was found to be higher and more important than the female students $(p<0.05)$. As a result, healthy living behaviors scores of students were found to be moderate in this study. ${ }^{[8]}$

As a result of another descriptive study to determine the healthy living behaviors and affecting demographic factors of 336 students in Health College, student nurses had the highest score from health responsibility and the lowest score from physical activity. In total score, female students have a higher average score than male students. It was determined that the income levels of the students affected the feeding behavior. As a result, healthy living behaviors scores of students were found to be moderate in this study. ${ }^{\left[{ }^{[]}\right.}$

In a research conducted on 159 students with the aim of determining and correlating the physical activity levels and healthy living behaviors of the students in the School of Physical Education and Sports (SPES), "International Physical Activity Evaluation Questionnaire" (determined as inactive, minimum active and HEPA active groups by MET method) short form and "Healthy Living Behaviors Scale" were used to determine the physical activity levels of students. While SPES students were included in the HEPA ac- tive group in terms of their total level of physical activity, it was found that they had a high score that could be considered as high in terms of their total living score. As a result of the Pearson Product Moment Correlation analysis, it was found that there is a significant positive relation between physical activity level $(r=0.223 ; p<0.01)$, health responsibility $(r=0.236 ; p<0.01)$, stress management $(r=0.192 ; p<0.05)$, self-actualization $(r=0.173, p<0.05)$ and healthy living behavior $(r=0.279 ; p<0.01)$ of the students who participated in the research. As a result, findings in the study can be put in the words that healthy living behaviors of students are effective in determining the level of physical activity. ${ }^{[10]}$

In a study conducted to determine the importance of health and living behaviors of the students of the Division of Physical Education and Sport in Teaching Department $(n=195)$, it was determined that income level, body mass index, alcohol habits are effective in healthy living behaviors and according to HLBS score, healthy living behaviors of students are moderate. ${ }^{[11]}$

As a result of another study conducted to determine healthy living behaviors of nursing students in Health College students ( $n=234$ ), the lowest score was obtained from exercise and the highest score was obtained from interpersonal support and self-actualization when the average score taken from the subdimensions of the HLSBS was examined. There is no significant difference between the total scores of female and male that they took from the HLSBS. Exercise and stress management scores were higher in male and the difference between the groups was significant $(p<0.05)$. It was determined that the students who evaluated the general health perception as "good" had a higher average score of self-actualization and nutrition subgroups. ${ }^{[12]}$

As a result of a descriptive study to determine healthy living behaviors and affecting factors of nursing school $(n=158)$ and classroom teachers school students $(n=180)$; HLSBS score averages of female students were detected as higher than male students; were higher in the students who state their health status as good, than those who stated their health status as moderate and bad; also were higher in the students who stated their success status as good, than those who stated their success status moderate and bad; higher in those who stopped smoking than smokers and non smokers; and were higher in students who do sports than those who do not do sports $(p<0.05)$. It has been determined that students' gender, department, health status, level of success, taking education related to health promotion, smoking and sporting activities affect healthy living behaviors. ${ }^{[13]}$ In a descriptive study to determine the healthy life behaviors of the students in the first year of Health Care Vocational School of higher educa- 
tion students $(\mathrm{n}=251)$, the mean age of the students were $20.46 \pm 3.7 ; 70.5 \%$ were female; $90.2 \%$ of them were bachelor; $69.3 \%$ of them were living in the family houses; $16 \%$ of them were living in the dormitories, $14.7 \%$ live in the student houses; $27.9 \%$ of them are both studying and working and $77.7 \%$ of their mothers had graduated from secondary school at the most. The average score of the total SYBD scale of the students was found to be moderate. The students with mothers who had a high education level, were not statistically significant, although the average score of interpersonal relations was high. Nutrition, interpersonal relations and total mean score of the students with high educated mothers were significant $(p<0.05) .{ }^{[14]}$ In the descriptive and cross-sectional study with the aim of determining how healthy the living of 320 students are, the survey form prepared by researchers Health-Promoting Living Profile (HPLP; Walker, Sechrist \& Pender, 1987) The Measurement of Coping With Stress (WCCL; Aysan, 1988, 1994) and Beck Depression Inventory (BDI; Hisli, 1988; Şahin, 1989; Teğin, 1980) were applied. As a result of the research, it was determined that students did not have sufficient knowledge to maintain a healthy living, did not use effective methods to cope with stress, and $40 \%$ of them were depressed. ${ }^{[15]}$ In a study conducted on 281 of students as a descriptive study to determine healthy living behaviors of nursing students, according to sociodemographic features of students, their frequency to go to health centers and also mouth/dental health centers, their state of doing sports and participation at social events, nutritional habits, having any chronic disease in themselves or their family members, a statistically significant difference was found between average scores of Healthy Living Behaviors II Scale. However, no statistically significant difference was found between the average scores of the Healthy Living Behaviors II Scale and the number of people in the students' families and the amount of cigarettes they smoke. ${ }^{[16]}$ In a study conducted on 404 students who attend in the departments of nursing, physiotherapy and rehabilitation, nutrition and dietetics; in the first, second and third grades of a university with the aim of defining healthy living behaviors, self-efficiency-sufficiency levels and affecting factors of university students, descriptive features form, Healthy Living Behaviors-II (SYBD) Scale and Self-Efficiency-Sufficiency scale were used as data collecting means. The self-efficiency-sufficiency level and healthy living behavior scores of the students were found to be moderate. It was found that the total score of selfefficiency-sufficiency level and healthy living behaviors of nursing students were significantly higher $(p<0.05)$. Healthy living behaviors of those who stated their general health status as "good"; self-efficiency-sufficiency levels of those who are in the first grade, those with a chronic disease and those whose mothers have a primary school education, were found to be statistically significantly higher $(p>0.05)$. A strong positive linear and statistically significant relationship was found between the SYBD-II and ÖEY total scores at an advanced level $(p>0.001) .{ }^{[1]]}$ As a result of a descriptive study to determine healthy living behaviors and affecting factors of the students $(n=480)$ in a vocational school of higher education; the mean score of the students taken from the HLBS II was determined as $127.05 \pm 20.35$. It was determined that the health responsibility, nutrition, stress management subgroup score of the female students were statistically significantly higher than the males' $(p<0.01)$; it was found that the health responsibility of the students increases as the educational background level of the parents increases; it was also determined that the healthy living behaviors of students who have any hobbies and do regular exercise, were statistically significantly higher $(p<0.01){ }^{[18]}$ In a study conducted among 156 of students who study in the first and second grades of Health College, in order to determine the factors affecting health promotion behavior of health college students; the researchers were trained students who participated in the research, on self-examination of breasts, testicular examination, prevention of gynecological cancers, nutrition, harms of smoking, finally exercise and its importance. The mean score of healthy living behaviors scale was $122.1 \pm 19.8$ before training; and there was no significant difference between the HLSBS scores of the students according to sex, high school graduated, department, economic level of the family and family type ( $p>0.05$ ). Three months after the training, the HLSBS score of students was determined as $125.3 \pm 17.4$, and a significant difference was found between the results of pre-training and post-training periods after three months $(p<0.05) .^{[19]}$

\section{CONCLUSION}

In the light of the results of current research on healthy living behaviors and related factors, efforts directed to increase awareness about healthy living behaviors and related factors, to comprehend the importance of healthy living behaviors and to make these behaviors into living should be supported. Considering priority groups that can be intervened in terms of healthy living behaviors, students who live in a dormitory should be encouraged in terms of physical activity because they have less physical activity. In terms of spiritual improvement and interpersonal relationships of the students, those who have the risky low socioeconomic status should be supported by the participation in social programs. ${ }^{[3]}$ Life experience, socioeconomic status and self-efficiency-sufficiency have a significant impact on the acquisition of healthy living behaviors. It is thought that the improvement of self-efficiency-sufficiency and 
programs that strengthen healthy living behaviors will have an important influence on students' lives. ${ }^{[17]}$

It is important that educational programs should be created with taking into account the factors that affect healthy living behaviors; and these programs should be made a part of the curriculum to be disseminated to all the educational years. It is important to increase the number of courses related to health protection and promotion in the education programs; and to educate the students in this regard; and also to educate the students who will take parts in the health services to comprehend the importance of health promotion behaviors and to transform their knowledge into behavior. It is important that plans and projects should be conducted by the students for the improvement of healthy living behaviors. More research should be conducted on students' health behaviors (exercise, nutrition, stress management, interpersonal support) and the results should be emphasized in the relevant places in the curriculum in the faculties where medical and health sciences are taught and the targets in the curriculum on this subject should be evaluated.

\section{Disclosures}

Peer-review: Externally peer-reviewed.

Conflict of Interest: None declared.

\section{REFERENCES}

1. Cihangiroğlu Z, Deveci SE. Fırat Üniversitesi Elazığ Sağlık Yüksekokulu öğrencilerinin sağlıklı yaşam biçimi davranışları ve etkileyen faktörler. Fırat Tıp Dergisi 2011;16(2):78-83.

2. İlhan N, Batmaz M, Akhan LU. Üniversite öğrencilerinin sağlıklı yaşam biçimi davranışları. Maltepe Üniversitesi Hemşirelik Bilim ve Sanatı Dergisi 2010;3(3):34-44.

3. Şimşek H, Öztoprak D, İkizoğlu E, Safalı F, Yavuz Ö, Onur Ö, et al. Tıp fakültesi öğrencilerinde sağlıklı yaşam biçimi davranışları ve ilişkili etmenler. DEÜ Tıp Fakültesi Dergisi 2012;26(3):151-7.

4. Açıksöz S, Uzun Ş, Arslan F. Hemşirelik öğrencilerinin sağlık algısı ile sağlığı geliştirme davranışları arasındaki ilişkinin incelenmesi. Gülhane Tıp Derg 2013;55:181-7.

5. Kocaakman M, Aksoy G, Eker HH. İstanbul ilindeki hemşirelik yüksekokulu öğrencilerinin sağlıklı yaşam biçimi davranışları. S.D.Ü. Tıp Fak Derg 2010:17(2):19-24.

6. Tuygar, ŞF, Arslan M. Sağlık hizmetleri meslek yüksekokulu öğrencilerinin sağlıklı yaşam biçimi davranışlarının incelen- mesi. SDÜ Sağlık Bilimleri Enstitüsü Dergisi 2015;6(2):59-66.

7. Duran Ö, Sümer H. Ebelik öğrencilerinin sağlıklı yaşam biçimi davranışları ve etkileyen faktörler. Anadolu Hemşirelik ve Sağlık Bilimleri Dergisi 2014;17(1):40-9.

8. Tambağ H. Hatay Sağlık Yüksekokulu öğrencilerinin sağlıklı yaşam biçimi davranışları ve etkileyen faktörler. Sağlık Bilimleri Fakültesi Hemşirelik Dergisi 2011;18(2):47-58.

9. Özyazıcıoğlu N, Kılıç M, Erdem N, Yavuz C, Afacan S. Hemşirelik öğrencilerinin sağlıklı yaşam biçimi davranışlarının belirlenmesi. Uluslararası İnsan Bilimleri Dergisi 2011;8(2):277-332.

10. Bozkuş T, Türkmen M, Kul M, Özkan A, Öz Ü, Cengiz C. Beden Eğitimi ve Spor Yüksekokulu'nda öğrenim gören öğrencilerin fiziksel aktivite düzeyleri ile sağlıklı yaşam biçimi davranışlarının belirlenmesi ve ilişkilendirilmesi. International Journal of Science Culture and Sport 2013;1(3):49-65.

11. Sivrikaya AH, Sivrikaya SK, Altun ÖŞ. Beden Eğitimi ve Spor Yüksekokulu Öğretmenlik Bölümü öğrencilerinin sağlıklı yaşam biçimi davranışlarının incelenmesi. Balıkesir Sağlık Bilimleri Dergisi 2013;2(3):133-8.

12. Yılmazel G, Çetinkaya F, Naçar M. Hemşirelik öğrencilerinde sağlığı geliştirme davranışları. TAF Preventive Medicine Bulletin 2013;12(3):261-70. [CrossRef]

13. Kostak MA, Kurt S, Süt N, Akarsu Ö, Ergül GD. Hemşirelik ve sınıf öğretmenliği öğrencilerinin sağlıklı yaşam biçimi davranışları. TAF Preventive Medicine Bulletin 2014:13(3):189-96. [CrossRef]

14. Şen MA, Ceylan A, Kurt ME, Palancı Y, Adın C. Sağlık hizmetleri meslek yüksekokulu öğrencilerinin sağlıklı yaşam biçimi davranışları ve etkileyen faktörler. Dicle Tıp Dergisi 2017;44 (1):1-11. [CrossRef]

15. Karadağ $M$, Yıldırım N. Health behaviors in health sciences university students in Turkey. Social Behavior and Personality 2010;38(1):43-52. [CrossRef]

16. Aksoy $T$, Uçar H. Hemşirelik öğrencilerinin sağlıklı yaşam biçimi davranışları. Hacettepe Üniversitesi Hemşirelik Fakültesi Dergisi 2014;1(2):53-67.

17. Örnek ÖK, Kürklü A. Üniversite öğrencilerinin sağlıklı yaşam biçimi davranışları, öz etkililik-yeterlilik düzeyleri ve etkileyen faktörler. Türkiye Klinikleri J Nurs Sci 2017;9(3):207-17. [CrossRef]

18. Vural PA, Bakır N. Meslek yüksekokulu öğrencilerinin sağlıklı yaşam biçimi davranışları ve etkileyen faktörler. Acıbadem Üniversitesi Sağlık Bilimleri Dergisi 2015;6(1):36-42.

19. Çelik GO, Malak AT, Bektaş M, Yılmaz D, Yümer AS, Öztürk Z, et al. Sağlık yüksekokulu öğrencilerinin sağlığı geliştirme davranışlarını etkileyen etmenlerin incelenmesi. Anatol J Clin Investig 2009;3(3):164-9. 